\title{
INFRASTRUKTURA PRZESTRZENI KONSUMPCJI WE WSPÓŁCZESNYCH MIASTACH W POLSCE ${ }^{1}$
}

\section{Wprowadzenie}

Przestrzeń miejska związana z konsumpcją tworzy odrębną infrastrukturę, która sprzyja konsumowaniu dóbr, usług oraz zagospodarowywaniu czasu wolnego, zaspokaja, ale równocześnie kreuje potrzeby mieszkańców miast, a także pełni szereg istotnych funkcji społecznych, ekonomicznych oraz architektoniczno-urbanistycznych. Celem opracowania jest scharakteryzowanie infrastruktury przestrzeni konsumpcji w centrach wybranych miast wojewódzkich w Polsce, opis zachodzących w ich obrębie przemian oraz ocena powiązań pomiędzy poszczególnymi elementami analizowanej infrastruktury. Wybór analizowanych miast wynika z jednej strony z relatywnie wysokiej, a równocześnie zróżnicowanej dynamiki rozwoju infrastruktury przestrzeni konsumpcji, z drugiej zaś podyktowany jest odmienną tradycją miejską w każdym z tych ośrodków oraz usytuowaniem w odmiennych gospodarczo i kulturowo regionach kraju. W każdym z tych miast przestrzeń konsumpcji była organizowana i reorganizowana w innym trybie administracyjnym, przy odmiennych postawach i działaniach zarówno władz miasta, jak i jego mieszkańców.

\section{1. Źródła i metody badawcze}

Ze względu na złożony obszar badawczy opracowania korzystałam z szerokiego spektrum źródeł informacji. Do analizy zastanych źródeł informacji zastosowałam dwie metody badawcze, a mianowicie metodę analizy dokumentów urzędowych, w tym

${ }^{1}$ Opracowanie powstało na podstawie autorskiego badania pt. „Infrastruktura przestrzeni konsumpcji we współczesnych miastach w Polsce” przeprowadzonego w Kolegium Ekonomiczno-Społecznym Szkoły Głównej Handlowej w Warszawie w ramach BMN 2013 (KES/BMN/11/13). 
danych statystycznych zgromadzonych przez GUS oraz informacji umieszczanych na oficjalnych stronach internetowych miast, a także metodę analizy treści w odniesieniu do czasopism naukowych, raportów firm badawczych działających na rynku nieruchomości (np. Property News, Jones Lang LaSalle) oraz artykułów w prasie lokalnej.

Analizy materiałów wtórnych wzbogaciłam wynikami zwiadu badawczego, w którego trakcie w każdym z badanych miast spędziłam od dwóch do pięciu dni, eksplorując przestrzenie konsumpcji, rozmawiając $z$ ich użytkownikami, robiąc dokumentację fotograficzną i zapisując wyniki obserwacji zewnętrznej.

Przestrzeń konsumpcyjna Poznania i Łodzi znajduje się w centrum zainteresowania badaczy oraz firm analizujących rynek nieruchomości komercyjnych. Z tego powodu dostępnych jest wiele opracowań i analiz na ich temat. Natomiast przestrzeń konsumpcyjna Kielc i Białegostoku pozostaje poza obszarem zainteresowania zarówno naukowców, jak i firm doradczych, a w rezultacie w raportach i analizach, a także w literaturze przedmiotu jest pomijana. $Z$ tego powodu $w$ badaniu tych dwóch miast informacje umieszczane na stronach internetowych urzędów miasta, analiza prasy lokalnej oraz wyniki zwiadu badawczego były szczególnie cennym źródłem informacji.

\section{Infrastruktura przestrzeni konsumpcji w Poznaniu, Kielcach, Białymstoku i Łodzi}

W opracowaniu koncentruję się na analizie szczególnego rodzaju infrastruktury społecznej, czyli infrastruktury miejskiej przestrzeni konsumpcji. Na podstawie wnikliwej analizy literatury przedmiotu ${ }^{2}$ przyjmuję definicję operacyjną infrastruktury miejskiej przestrzeni konsumpcji i definiuję ją jako system obiektów i przestrzeni, które zaspokajają, ale równocześnie kreują konsumenckie, rekreacyjne i kulturalne potrzeby mieszkańców miasta. Na infrastrukturę miejskiej przestrzeni konsumpcji składają się nowoczesne centra handlowe, zwane też galeriami handlowymi, rynki i ulice handlowe wraz z lokalizowanymi przy nich obiektami handlowo-usługowymi.

\footnotetext{
${ }^{2}$ M. Błaszczyk, S.W. Kłopot, J. Pluta, Stare i nowe problemy społeczne wielkiego miasta. Socjologiczne studium konsumpcji na przykładzie Wrocławia, Wydawnictwo Naukowe Scholar, Warszawa 2010; M. Castells, Kwestia miejska, PWN, Warszawa 1982 (I wydanie 1972); M. Dymnicka, Przestrzeń publiczna a przemiany miasta; B. Jałowiecki, Społeczna przestrzeń metropolii, Wydawnictwo Naukowe Scholar, Warszawa 2000; B. Jałowiecki, Społeczne wytwarzanie przestrzeni, Książka i Wiedza, Warszawa 2010; A. Majer, Socjologia i przestrzeń miejska, PWN, Warszawa 2010, s. 68; G. Rutkowska, Analiza porównawcza infrastruktury technicznej i społecznej w wybranej gminie $z$ wymogami UE, „Przegląd Naukowy. Inżynieria i Kształtowanie Środowiska" 2007, z. 2 (36).
} 
Do analizy wybrałam te elementy infrastruktury przestrzeni konsumpcji, które znajdują się w centrach badanych miast, w niewielkiej odległości od siebie. Taka lokalizacja umożliwia potencjalnym klientom relatywnie łatwe i szybkie przemieszczanie się między nimi, a bliskie położenie sprawia, że elementy te znacząco wpływają na siebie nawzajem, konkurują ze sobą, a czasem uzupełniają swoją ofertę, co umożliwia badaczowi ocenę zachodzących między nimi relacji. W przestrzeni Poznania do najważniejszych elementów infrastruktury przestrzeni konsumpcji należą: Stary Rynek, ulica Półwiejska oraz najważniejsza galeria handlowa zlokalizowana w centrum miasta: Centrum Handlu, Sztuki i Biznesu Stary Browar. Najważniejsze dla mieszkańców Kielc elementy infrastruktury przestrzeni konsumpcji to rynek, główny deptak - ulica Sienkiewicza, dwie śródmiejskie galerie handlowe: Echo i Korona. W przestrzeni Białegostoku charakteryzuję rynek, ulicę Lipową oraz dwie galerie handlowe: Białą i Alfę, w Łodzi analizuję centrum miasta, które w zależności od przemian historycznych zmieniało swe położenie, ulicę Piotrkowską oraz centrum handlowe Manufaktura.

\subsection{Rynki}

Pierwszym omawianym typem infrastruktury przestrzeni konsumpcji są rynki. Tradycyjnie stanowiły one ważną przestrzeń centralną, pełniącą funkcje handlowe oraz integracyjne. Były to miejsca spotkań towarzyskich i spędzania wolnego czasu. Obecnie znaczenie rynków podlega dynamicznym przemianom, a ich centralna funkcja często maleje. Rynki, jeśli otaczają miejsca pamięci, pomniki, figury świętych i obeliski, mogą również pełnić funkcje symboliczne ${ }^{3}$.

Analizę rozpocznę od charakterystyki rynku w Poznaniu, którego historia sięga 1253 r., kiedy Poznań został lokowany na prawie niemieckim przez księcia Przemysła I. Znaczenie rynku w Poznaniu rosło wraz z rozwojem miasta, np. poprowadzenie przez niego w 1880 r. pierwszej w Poznaniu linii tramwajowej zwiększyło jego dostępność komunikacyjną. Dzięki tej zmianie atrakcyjność rynku jako miejsca handlu wzrosła, pojawiły się pierwsze kilkupiętrowe, nowoczesne domy towarowe, dominowały sklepy odzieżowe, obuwnicze, z kapeluszami i czapkami, powstało także kilka restauracji. W tym czasie handel żywnością został przeniesiony na boczne ulice, funkcję targowiska przejął zaś plac Sapieżyńskich. Po 1918 r. Stary Rynek oprócz funkcji handlowej zaczął pełnić funkcję reprezentacyjną. Jego rozwój przerwała druga wojna światowa, w której wyniku 60\% rynku zostało zniszczone. Odbudowę

\footnotetext{
${ }^{3}$ K. Bierwiaczonek, B. Lewicka, T. Nawrocki, Rynki, malle i cmentarze. Przestrzeń publiczna miast ślqskich w ujęciu socjologicznym, Wydawnictwo Nomos, Kraków 2012, s. 37.
} 
Starego Rynku zakończono dopiero w 1967 r., a w 1970 r. zamknięto na nim i na sąsiednich ulicach ruch samochodowy. Postanowiono wtedy, że rynek będzie pełnił kulturalną, reprezentacyjną i mieszkalną funkcję, nie przywrócono natomiast historycznie ukształtowanej funkcji handlowej. Te założenia spowodowały wyludnienie rynku, jego ożywienie nastąpiło dopiero w latach 90. XX w. w rezultacie powstawania coraz liczniejszych restauracji, kawiarni, klubów i pubów ${ }^{4}$. Wokół Ratusza, na prowizorycznych stoiskach sprzedawane są pamiątki, a na rynku mają miejsce różne wydarzenia, np. w trakcie mojego pobytu badawczego odbywał się pokaz zabytkowych samochodów. W rezultacie rynek pełni funkcje reprezentacyjne oraz rekreacyjno-rozrywkowe, jest uważany za centrum życia miasta ${ }^{5}$. Dobry system komunikacji miejskiej pozwala łatwo dotrzeć do rynku z innych części Poznania.

Rynek w Poznaniu koncentruje kulturę: znajduje się tu sześć muzeów, raz w roku odbywa się na nim tygodniowy Jarmark Świętojański. Oprócz placówek kulturalnych na rynku dominują obiekty gastronomiczne i klubowe, czyli zgodnie z założeniem $\mathrm{z}$ lat 70. funkcja rekreacyjna dominuje nad handlową. Istnieje również kilka galerii sztuki, sklepów z antykami, z biżuterią, siedem sklepów z pamiątkami. Nieliczne są natomiast sklepy z odzieżą i obuwiem, brakuje lokali spożywczych. Sklepy nie służą więc zaspokajaniu codziennych potrzeb, lecz skierowane są do specyficznego odbiorcy.

Drugim omawianym rynkiem jest wytyczony w XIV w. rynek w Kielcach ${ }^{6}$, który do dzisiaj wyznacza centralny punkt miasta. Począwszy od XVIII w. aż do XX w. otaczające rynek pola uprawne były sukcesywnie zastępowane przez murowane kamienice mieszczańskie, w których obecnie znajdują się m.in. restauracje, Muzeum Narodowe, kielecki oddział „Gazety Wyborczej”. Po zachodniej stronie rynku znajduje się wybudowany w 1834 r. ratusz, w którym zlokalizowany jest Urząd Miasta Kielce. Obecny ratusz został odbudowany po wielkim pożarze w roku 1800, w którego wyniku spłonął pierwszy budynek ratusza. Do 2008 r. na środku rynku znajdowała się stworzona w dawnym zbiorniku przeciwpożarowym fontanna, a wokół niej kwiaty, drzewa i ruchliwe rondo. Rynek, choć wyznaczał centrum miasta, pełnił funkcję wyłącznie komunikacyjną. Duży ruch samochodowy wykluczał rekreacyjną funkcję rynku, uniemożliwiał też stworzenie infrastruktury sprzyjającej integracji i wypoczynkowi, a zielony, zaniedbany skwer nie zachęcał do spędzania na nim czasu. W 2008 r. postanowiono zmienić wygląd i funkcje rynku. Zlikwidowano

${ }^{4}$ A. Cegłowska, R. Matykowski, Przestrzenie publiczne i ich znaczenie w dużym mieście, w: Studia miejskie. Funkcje miast jako czynnik kształtowania przestrzeni miejskiej, red. J. Słodczyk, A. Dembicka-Niemiec, Opole 2010, s. 245-246.

${ }^{5}$ Ibidem.

${ }^{6}$ J. Pazdur, Dzieje Kielc do 1863, Ossolineum, Wrocław 1971, s. 46-48. 
rondo i zminimalizowano ruch uliczny. Powierzchnię placu pokryto nawiązującą do dawnych czasów kostką brukową, a na środku postawiono pręgierz i pompę wodną. Wybudowano również klomby z drzewami, ławeczki i fontanny. Mieszkańcy krytykowali nowy wygląd miejsca, przede wszystkim ze względu na ograniczenie zieleni miejskiej, dlatego postanowiono pobudzić życie w tej przestrzeni i zaprojektowano tzw. salon miejski ${ }^{7}$, czyli strefę rekreacyjno-wypoczynkową. Na rynku ustawiono dodatkowe donice $\mathrm{z}$ drzewami, leżaki, dodatkowe ławki, fotele, hamaki, trampolinę i poduszki dla dzieci'. Projekt „,salonu miejskiego” powstał po konsultacjach architektów z mieszkańcami na temat ich preferencji odnośnie do wyglądu i funkcjonowania rynku. Z konsultacji jednoznacznie wynikło, że preferencją mieszkańców jest to, aby rynek był zielony (32\% głosów) $)^{9}$. Urządzanie „salonu miejskiego” stało się jednym z elementów podjętych działań i szerszej dyskusji w Kielcach na temat potrzeby ożywienia centrum miasta. W związku z tym prezydent Kielc powołał „menedżera centrum Kielc", który miał ożywić centrum, niestety, jego działalność okazała się nieskuteczna i po pięciu miesiącach został on odwołany.

Trzecim omawianym rynkiem jest rynek w Białymstoku. Jego początki sięgają XV w., powstał on na skrzyżowaniu dróg wiodących do pobliskich miejscowości. Z czasem wokół placu zaczęły powstawać kolejne budynki - drewniany kościół około 1547 r., trzydzieści lat później karczma. Plan rynku wytyczono w 1708 r., jednak w wyniku późniejszych wydarzeń historycznych, czyli pożaru w połowie XVIII w., rozbudowy i renowacji w XIX w., zmiany charakteru miasta $\mathrm{z}$ rezydencjonalnego na administracyjny i przemysłowy oraz późniejszych zniszczeń wojennych kształt rynku podlegał wielu zmianom ${ }^{10}$. Współczesny rynek ma nieregularny, zbliżony do trójkątnego zarys. Obecną nazwę Rynek Tadeusza Kościuszki uzyskał w 1919 r. ${ }^{11}$ Rynek Kościuszki, jak piszą władze miasta, „przed wojną był prawdziwym sercem miasta. Tu skupiało się życie, tu handlowano, było to miejsce spotkań i spacerów"12. Podczas drugiej wojny światowej rynek został zupełnie zniszczony, a po wojnie w trakcie odbudowy przed ratuszem utworzono skwer z drzewami, który szybko stał się miejscem spożywania alkoholu przez różne grupy społeczne, co przyczyniło się do „zamarcia

\footnotetext{
7 Pojęcia „salon miejski” używa Bohdan Jałowiecki - w prowadzonych przez niego badaniach percepcji przestrzeni Warszawy w 1980 r. badani określali Stare Miasto i Łazienki tym mianem. Za: B. Jałowiecki, Percepcja przestrzeni Warszawy, „Studia Regionalne i Lokalne” 2000, nr 2 (2), s. 86.

8 P. Burda, Hamaki już kołysza. Uroczyście otwarto salon miejski na kieleckim rynku, 4.08.2013, http:// www.echodnia.eu/apps/pbcs.dll/article?AID=/20130804/POWIAT0104/130809559, dostęp 5.11.2013.

${ }_{9}$ Institute of design Kielce, http://www.idkielce.pl/pl/wydarzenia/aktualne/90-wplyn-na-rynek, dostęp 7.11.2013.

${ }^{10}$ M. Kietliński, Archiwum Państwowe w Białymstoku, http://www.bialystok.ap.gov.pl/teksty/rynek_ kosciuszki.pdf, dostęp 15.11.2013.

${ }^{11}$ Ibidem.

12 M. Hołownia, Białystok 2006-2010, Urząd Miejski w Białymstoku, Białystok 2010, s. 6.
} 
tej części centrum"13. W 2007 r. postanowiono zmodernizować rynek, m.in. poprzez likwidację wspomnianego skweru (pozostawiono tylko nieliczne drzewa). Miejsce pozostałe po skwerze wybrukowano, porozstawiano również donice z drzewami. Plany modernizacji były krytykowane, równie silne kontrowersje i sprzeciw budziły plany zamknięcia rynku dla ruchu samochodowego ${ }^{14}$. Mimo braku zgody co do przyszłego kształtu rynku zmiany wprowadzono, a w sierpniu 2009 r. uroczyście otwarto zmodernizowany rynek. Prezydent miasta, Tadeusz Truskolaski, mówił, że jest to „miejski salon”, w którym przyjmuje się gości, który świadczy o całym mieście.

Czwarty analizowany w opracowaniu rynek znajduje się w Łodzi. Łódź uzyskała status miasta na początku XV w. i przez cztery wieki funkcjonowała jako niewielki ośrodek rolniczo-rzemieślniczy o zasięgu lokalnym. Centrum miasta wykształciło się na przecięciu głównych traktów handlowych w miejscu nazywanym odtąd Starym Rynkiem ${ }^{15}$. Nadanie Łodzi praw miasta fabrycznego w 1820 r. zmieniło jej charakter i przyczyniło się do wytworzenia nowego centrum. W latach 1821-1823 na południe od dotychczasowej rolniczej Łodzi zbudowano osadę dla sukienników Nowe Miasto, tam też zlokalizowano ośmioboczny rynek z kościołem i ratuszem, nazywany Rynkiem Nowego Miasta, na którym znalazł się również początek ulicy Piotrkowskiej. W latach 1824-1828, ze względu na brak miejsc w Nowym Mieście dla napływających osadników, na południe od Rynku Nowego Miasta, wzdłuż ulicy Piotrkowskiej stworzono drugą osadę przemysłową. W następnych latach przy ulicy Piotrkowskiej budowano domy tkaczy, fabrykantów, bankierów, robotników, mieszkali tu również aktorzy, artyści, prawnicy, lekarze, budowano fabryki, hotele, teatry i luksusowe sklepy. Ulica stała się forum życia miejskiego, a centrum miasta, które początkowo przesunęło się z Rynku Starego miasta na Rynek Nowego Miasta, szybko zmieniło lokalizację na ulicę Piotrkowską, która stała się osią rozwoju urbanistycznego miasta.

\subsection{Główne ulice handlowe}

Ulice handlowe to drugi typ omawianej w opracowaniu infrastruktury miejskiej przestrzeni konsumpcji. Są one jednym z najstarszych elementów miasta. Punkty sprzedaży usytuowane wzdłuż dróg, towarzyszące zabudowie mieszkaniowej na parterach budynków i w piwnicach to tzw. linearne formy handlu. Ulice handlowe są

${ }^{13}$ Ibidem.

${ }^{14}$ Ibidem, s. 8.

${ }^{15}$ M. Sobczyński, A. Wolaniuk, Współczesne tendencje przemian centrów dużych miast Polski na przykładzie Łodzi, Gdańska i Krakowa, w: Studia miejskie. Funkcje miast jako czynnik kształtowania przestrzeni miejskiej, red. J. Słodczyk, A. Dembicka-Niemiec, Opole 2010, s. 17. 
częścią miasta stanowiącą o jego prestiżu i randze, są uznawane za reprezentacyjną część miasta, często koncentrującą ekskluzywne sklepy ${ }^{16}$. Jeśli ruch samochodowy jest na nich zamknięty lub ograniczony, to stwarzają one warunki do interakcji społecznych i oprócz funkcji komunikacyjnej pełnią wiele innych funkcji: handlowe, usługowe, rekreacyjne. Ich znaczenie dla miasta i społeczności miejskiej, podobnie jak znaczenie rynków, zmieniało się dynamicznie wraz $\mathrm{z}$ historycznymi przemianami ${ }^{17}$.

W oficjalnych materiałach promocyjnych miasta Poznania jako główne trakty handlowe wymieniane są cztery ulice: Paderewskiego, Półwiejska, 27 Grudnia, św. Marcina ${ }^{18}$. Jednak mieszkańcy miasta, pytani przeze mnie o główne ulice handlowe, wskazywali ulicę Półwiejską, z tego powodu analizę ulic handlowych w Poznaniu ograniczę jedynie do tego traktu. Ulica Półwiejska długo była najważniejszym deptakiem handlowym w Poznaniu. Po 1989 r. rozkwitał tutaj handel uliczny, który potem przeniósł się do zlokalizowanych wzdłuż ulicy kamienic. W 2001 r. przy ulicy Półwiejskiej otworzono Centrum Handlowo-Biurowe Kupiec Poznański, a w 2003 r. Centrum Sztuki i Biznesu Stary Browar. Te inwestycje w sposób znaczący przyczyniły się do spadku znaczenia handlowego tej ulicy i do jej degradacji. Z lektury prasy lokalnej wynika, że mimo zakazów mieszkańcy traktują ulicę Półwiejską jako rodzaj parkingu dla samochodów ${ }^{19}$, co również nie dodaje jej atrakcyjności. Sytuacja taka dziwi, gdyż w 2004 r. podjęto starania w kierunku nadania jej prestiżowego charakteru: zmieniono nawierzchnię, postawiono stylowe latarnie, ławki oraz donice $\mathrm{z}$ kwia$\operatorname{tami}^{20}$. W literaturze przedmiotu ulica jest opisywana jako główny trakt handlowy miasta, myślę jednak, że z upływem czasu staje się to coraz mniej adekwatny opis. Nową funkcją ulicy Półwiejskiej stało się w dużym stopniu bycie drogą wiodącą od Starego Browaru do Starego Rynku.

Główną ulicą handlową Kielc jest ulica Sienkiewicza, która jest osią miasta, skupia jego życie towarzyskie, pełni funkcje reprezentacyjne i turystyczne, jest miejscem nawet ważniejszym niż rynek. Ulica Sienkiewicza jeszcze dziesięć lat temu była najważniejszym miejscem handlu w mieście, obecnie ze względu na konkurencję zlokalizowanych w pobliżu dwóch centrów handlowych dotychczasowe znaczenie ulicy

\footnotetext{
16 T. Kaczmarek, Struktura przestrzenna handlu detalicznego. Od skali globalnej do lokalnej, Wydawnictwo Naukowe Bogucki, Poznań 2010, s. 9-52.

${ }_{17}$ K. Bierwiaczonek, B. Lewicka, T. Nawrocki, op.cit., s. 37; por. B. Jałowiecki, M. Szczepański, Miasto i przestrzeń w perspektywie socjologicznej, wyd. 2, Wydawnictwo Naukowe Scholar, Warszawa 2009, s. 395-405.

${ }_{18}$ Materiały promocyjne miasta Poznania, Zakupy, w: Poznań warto zobaczyć, http://www.poznan.pl/ $\mathrm{mim} /$ turystyka/pobierz-folder-publikacje,p,16577.html, dostęp 26.09.2013.

19 Portal informacyjny miasta Poznania, http://poznan.naszemiasto.pl/artykul/galeria/2014360,parkowanie-w-poznaniu-na-cwaniaka-na-polwiejskiej-zdjecia,id,t.html, dostęp 7.10.2013.

${ }^{20}$ Portal informacyjny miasta Poznania, http://www.poznan.pl/mim/wiadmag/news/rusza-remont-ulicy-polwiejskiej,1381.html, dostęp 7.10.2013.
} 
w dużym stopniu zmalało. Miejsce sklepów, które przeniosły swe lokale do centrów handlowych, zastąpiły filie zagranicznych banków, operatorów komórkowych, a także kancelarie adwokackie, biura porad prawnych, gabinety lekarskie. Również działające tu od wielu lat trzy domy towarowe: Puchatek, Katarzyna i Tęcza straciły popularność. Zaplanowane modernizacje tych obiektów mają powstrzymać negatywny trend. Przy ulicy Sienkiewicza działają drobne punkty usługowe, takie jak cukiernie i lodziarnie, oraz większość kieleckich dyskotek, pubów i restauracji, co sprawia, że mimo spadku znaczenia funkcji handlowej ulica dalej jest ważnym miejscem spotkań i spędzania wolnego czasu przez kielczan. Ulica Sienkiewicza została w latach 2001-2006 przebudowana - jej nawierzchnię pokryto granitową kostką, postawiono stylowe latarnie i ławki. Zmiana wyglądu ulicy miała się przyczynić do lepszego pełnienia przez nią funkcji reprezentacyjnych.

Główną ulicą handlową w Białymstoku jest łącząca Rynek Kościuszki z placem Niepodległości ulica Lipowa. Przez wiele lat była ona reprezentacyjnym traktem oraz najważniejszą ulicą handlową w mieście. W latach 2011-2012 została gruntownie przebudowana - poszerzono przestrzeń dla pieszych, stworzono ścieżki rowerowe, ograniczono ruch samochodów oraz zmieniono nawierzchnię chodników - wyłożono je granitowymi płytami. Postawiono również fontanny, rzeźby miejskie, ławki, zmieniono oświetlenie ulicy oraz podświetlono najważniejsze zabytki ${ }^{21}$.

W ostatnich kilku latach reprezentacyjne i handlowe znaczenie ulicy zaczęło maleć. Przeprowadzony remont miał przywrócić jej atrakcyjność, spowodował jednak wiele trudności dla mieszkańców miasta i dla prowadzących na niej działalność przedsiębiorców. Remont ulicy utrudnił klientom dostęp do lokali handlowo-usługowych, zlikwidowano też wiele miejsc parkingowych, co przyczyniło się do dalszego spadku popularności robienia zakupów na ulicy Lipowej ${ }^{22}$. Należy jednak podkreślić, że mimo krytyki kierowanej przez kupców pod adresem władz miasta podejmują one działania mające na celu wspomożenie działalności handlowo-usługowej przy ulicy. W trakcie trwania remontu obniżono kupcom wysokość czynszu, równocześnie władze miasta starają się zachęcić mieszkańców do spędzania czasu i robienia zakupów w centrum miasta, o czym świadczy apel umieszczony na oficjalnym portalu miejskim: „Ponad 200 sklepów zlokalizowanych przy Rynku Kościuszki, ulicy Suraskiej, Lipowej i Jana Kilińskiego, placu Niepodległości i placu Jana Pawła II oferuje bogaty wybór towarów i usług. Robiąc zakupy w centrum Twojego miasta, wspierasz lokalną przedsiębiorczość, która często wsparta rodzinnym zaangażowaniem, przekłada się na szczególną

${ }^{21}$ Ruszy generalna przebudowa ulicy Lipowej, 2.02.2011, http://www.bialystokonline.pl/ruszy-generalnaprzebudowa-ulicy-lipowej, artykul,58167,1,1.html, dostęp 15.11.2013.

22 Ul. Lipowa. Kupcy załamani. Obroty spadty nawet o połowe, 1.05.2013, http://www.poranny.pl/apps/ pbcs.dll/article?AID=/20130501/BIALYSTOK/130429461, 15.11.2013. 
dbałość o wysoką jakość obsługi, zorientowanie na indywidualne potrzeby klienta oraz możliwość negocjacji cen”23.

$\mathrm{Na}$ tym samym portalu umieszczono też interaktywną mapę centrum z zaznaczonymi punktami handlowo-usługowymi na Rynku Tadeusza Kościuszki, na ulicy Lipowej oraz na ulicy Suraskiej, na której można wybrać szukany lokal handlowy lub usługowy.

Kolejną analizowaną ulicą handlową jest ulica Piotrkowska w Łodzi. Przez 200 lat, mimo ogromnego rozwoju ludnościowego i przestrzennego miasta, ulica Piotrkowska pełniła funkcję jego centrum, to przy niej lokalizowano najważniejsze instytucje administracji państwowej, kościelnej i finansowej ${ }^{24}$. W pierwszej dekadzie XXI w. sytuacja niepodważalnej dominacji przestrzennej i funkcjonalnej ulicy Piotrkowskiej zaczęła się zmieniać. Przyczyniły się do tego rosnące ceny najmu lokali handlowo-usługowych przy ulicy oraz powstawanie wielkopowierzchniowych obiektów handlowych. Momentem przełomowym dla ulicy Piotrkowskiej stało się otworzenie w jej bezpośrednim sąsiedztwie centrum handlowego Manufaktura. W wyniku wymienionych uwarunkowań funkcja handlowa ulicy Piotrkowskiej zaczęła maleć, sklepy, nie wytrzymując konkurencji, albo przenosiły swe lokale do galerii handlowej, albo bankrutowały. Ich miejsce zajęly instytucje administracji publicznej, wymiaru sprawiedliwości i finansowe, czyli banki, firmy ubezpieczeniowe, kancelarie adwokackie, notarialne $e^{25}$.

Władze Łodzi, świadome problemów, jakie dotykają centrum miasta, zaczęły realizować dwa programy rewitalizacji i ożywienia miasta. Pierwszy program pt. „Mia100Kamienic" polega na kompleksowej rewitalizacji XIX i XX-wiecznych kamienic ${ }^{26}$. Drugi projekt to stworzenie tzw. Nowego Centrum Łodzi, czyli dzielnicy, która ożywi łódzkie śródmieście, nada mu charakter miasta kreatywnego, zachęci turystów do przyjazdów, a przedsiębiorców do inwestycji ${ }^{27}$. Nowe Centrum Łodzi postanowiono zlokalizować na 100 hektarach terenu poprzemysłowego w okolicy ulicy Piotrkowskiej. Projekt zakłada stworzenie atrakcyjnych i bezpiecznych przestrzeni publicznych, rewitalizację obszarów poprzemysłowych i kolejowych, stworzenie nowych przestrzeni do inwestowania, zachowanie i zrewitalizowanie istotnych zabudowań stanowiących o tożsamości i historii Łodzi.

${ }^{23} \mathrm{http}: / / w w w . b i a l y s t o k . p l / 1191-t w o j e-c e n t r u m-m i a s t a / d e f a u l t . a s p x$, dostęp 14.11.2013.

${ }^{24}$ M. Sobczyński, A. Wolaniuk, op.cit., s. 19.

25 A. Wolaniuk, Centra miast, w: Geografia urbanistyczna, red. S. Liszewski, PWN, Warszawa 2012, s. 333.

${ }^{26}$ Oficjalna strona internetowa Urzędu Miasta Łódź, http://mia100kamienic.lodz.pl/, dostęp 20.11.2013.

${ }^{27}$ Strona internetowa projektu, http://www.ecllodz.pl/Nowe_Centrum_Lodzi,11, dostęp 20.11.2013. 


\subsection{Centra handlowe}

Kolejnym omawianym typem infrastruktury miejskiej przestrzeni konsumpcji są centra handlowe. Stały się one ważnymi elementami miejskiej przestrzeni konsumpcji, które ogniskują wiele funkcji, a równocześnie silnie oddziałują na pozostałe elementy infrastruktury miejskiej przestrzeni konsumpcji oraz na społeczno-ekonomiczny rozwój całego miasta. Centra handlowe charakteryzują się wielością i różnorodnością pełnionych funkcji: handlowych i usługowych oraz bardzo dużą powierzchnią. Aby obiekt był uznany za centrum handlowe, według Colliers International musi mieć minimalną powierzchnię 5 tys. $\mathrm{m}^{2}$ (według klasyfikacji EHI Retail Institute minimalną powierzchnią jest od 8 do 10 tys. $\mathrm{m}^{2}$ ). Definicja tego terminu wskazuje, że centrum handlowe to „skupisko obiektów handlowych pod jednym dachem i na znacznej powierzchni, na której działalność handlowa miesza się z innymi funkcjami usługowymi, tworząc dominanty i kluczowe miejsca konsumpcji współczesnego świata [...]. Centra handlowe łączą w sobie elementy ulicy handlowej, rynku, galerii i pasażu z małymi sklepami, domu towarowego (np. odzieżowego) i hipermarketu (np. spożywczego, budowlanego), a więc niemal wszystkie formy i koncentracje przestrzenne handlu wykształcane w różnych częściach miasta i w różnych etapach jego rozwoju" ${ }^{28}$. W każdym $\mathrm{z}$ analizowanych miast omawiam jedno największe i najważniejsze centrum handlowe lub dwa centra o podobnym znaczeniu i wielkości.

Pierwszą analizowaną galerią handlową jest Centrum Handlu Sztuki i Biznesu Stary Browar. Ta galeria handlowa położona w centrum Poznania, przy ulicy Półwiejskiej oraz w niedalekiej odległości od Starego Rynku powstała w budynku dawnej, wybudowanej w 1896 r. fabryki piwa. W 1998 r. obiekt został zakupiony przez należącą do Grażyny Kulczyk firmę Fortis, która przekształciła fabrykę w centrum sztuki i kultury. W latach 1999-2002 w budynku odbywały się przedstawienia teatralne i opery, a w 2004 r. otwarto pierwszy segment Centrum Handlu, Sztuki i Biznesu Stary Browar ${ }^{29}$. W jego przestrzeni skoncentrowano dziesiątki sklepów, restauracje, kawiarnie, kina, bary, kluby, odbywają się tu różne wystawy, koncerty, spektakle, plenerowe projekcje filmów w okresie letnim, nie brakuje również usług finansowych i bankowych, lokali telefonii komórkowych oraz usług medycznych ${ }^{30}$.

Obiekty Starego Browaru są powiązane z przyległym parkiem oraz z centrum biznesowym miasta, tworząc kompleks półotwartej przestrzeni publicznej łączącej zabyt-

\footnotetext{
${ }^{28}$ T. Kaczmarek, op.cit., s. 46; por. B. Jałowiecki, M. Szczepański, op.cit., s. 412-417.

${ }^{29}$ A. Cegłowska, R. Matykowski, op.cit., s. 247-48.

${ }^{30}$ Ibidem.
} 
kową architekturę z terenami zielonymi oraz z nowoczesnymi biurowcami (od strony ulicy Kościuszki). Jan Mikołajczyk w artykule poświęconym analizie oddziaływania Starego Browaru na rozwój społeczno-gospodarczy Poznania ${ }^{31}$ wskazuje korzyści $\mathrm{z}$ inwestycji, takie jak poprawa wyglądu budynku położonego w centrum miasta, zmiana funkcji Starego Browaru z produkcyjnej, generującej szereg uciążliwości, na funkcję handlowo-usługową, biznesową, kulturalną, zwiększenie liczby miejsc parkingowych, ożywienie, a także podniesienie atrakcyjności inwestycyjnej obszaru sąsiadującego ze Starym Browarem; powstanie obiektu będącego konkurencją dla centrów handlowych na obrzeżach miasta. Autor opracowania koncentruje się na zaletach inwestycji, ignorując negatywny wpływ centrum handlowego na pozostałą infrastrukturę przestrzeni konsumpcji w mieście. $Z$ jego tezami można polemizować, np. z zaskakującym twierdzeniem o ożywianiu obszaru sąsiadującego ze Starym Browarem. Wartość inwestycyjna okolicy na pewno wzrosła, powstał nowy trakt komunikacyjny, którym ludzie podążają do Starego Browaru, nie utożsamiałabym jednak tego zjawiska z ożywieniem przestrzeni.

Kolejne galerie handlowe, które analizuję w opracowaniu, to Galeria Echo i Galeria Korona w Kielcach. Pierwsze nowoczesne, wielofunkcyjne centrum handlowe w Kielcach to otworzona w 2002 r. Galeria Echo. Jej pojawienie się w znaczący sposób wpłynęło na dotychczasową infrastrukturę przestrzeni konsumpcji w tym mieście. W zlokalizowanej nieopodal rynku i ulicy Sienkiewicza Galerii Echo otworzono 80 sklepów, wyposażony w 7 sal Kinoplex, kawiarnie, restauracje $\mathrm{e}^{32}$. W latach 2009-2011 galerię dodatkowo rozbudowano i unowocześniono - w zmodernizowanym obiekcie znajduje się obecnie 300 sklepów. Druga Galeria Handlowa w Kielcach Galeria Korona - powstała w bezpośrednim sąsiedztwie rynku i ulicy Sienkiewicza. Reakcją na tę inwestycję były protesty kieleckich kupców, a ich niezadowolenie rosło wraz z ujawnianiem kolejnych wątpliwości w kwestii uchwalenia planu zagospodarowania przestrzennego, liczby kondygnacji budynku, kwestii przebudowy okolicznych ulic oraz małego zaplecza finansowego inwestora. Jednak mimo protestów kupców galeria handlowa Korona została otwarta w maju 2012 r. Ideą jej istnienia jest bycie „osią życia mieszkańców całego regionu” ${ }^{\text {”3 }}$. Nie pozostawia to wątpliwości, że celem Galerii Korona nie jest uzupełnianie oferty pozostałych elementów infrastruktury

31 J. Kuczyński, J. Mikołajczyk, Wpływ powstania i funkcjonowania Centrum Handlu, Sztuki i Biznesu Stary Browar na rozwój społeczno-gospodarczy Poznania, w: Zarzadzanie usługami w gospodarce rynkowej: handel, gastronomia, turystyka, red. J. Mikołajczyk, Wydawnictwo Wyższej Szkoły Handlu i Usług, Poznań 2007, s. 80.

${ }^{32}$ Strona internetowa Stowarzyszenia Kieleckie Inwestycje, http://www.inwestycje.kielce.pl/echo_galeria_echo.htm, dostęp 14.11.2013.

${ }_{33}$ Strona internetowa Galerii Korona w Kielcach, http://www.galeria-korona.pl/O-Galerii/Historia.html, dostęp 14.11.2013. 
przestrzeni konsumpcji, lecz ich zastąpienie. W ofercie obiektu jest 150 lokali handlowo-usługowych ${ }^{34}$, a więc o połowę mniej niż w ofercie Galerii Echo.

Oferta handlowo-usługowa Galerii Echo jest bogatsza od oferty Galerii Korona. Oferta kulturalna obydwu galerii ogranicza się do kina, ale Galeria Korona uzupełnia ją wieloma wydarzeniami: wyborami miss, konkursami graffiti, koncertami np. pieśni patriotycznych z okazji 11 listopada ${ }^{35}$. W galeriach są zlokalizowane banki, lokale telefonii komórkowych, nie ma jednak lokali medycznych ani biur, których posiadaniem charakteryzują się niektóre galerie handlowe w pozostałych analizowanych miastach.

Trzecim miastem, w którym omówię działalność galerii handlowych, jest Białystok. Jest to miasto, w którym handel bardzo długo opierał się na sprzedaży w małych sklepach oraz na targach. Pierwszy hipermarket został otworzony dopiero w $2000 \mathrm{r}$. i był to Auchan. Stał się on szybko popularnym miejscem zakupów - sklep na swojej stronie internetowej opisuje się jako „ulubione miejsce zakupów mieszkańców zarówno Białegostoku, jak i przyjaciół zza wschodniej granicy”36. Znaczące zmiany w infrastrukturze przestrzeni konsumpcji spowodowało pojawienie się dwóch nowoczesnych galerii handlowych: Atrium Biała w 2007 r. oraz Galerii Alfa otwartej w 2008 r. Interesujące jest, że w liczącym 300 tys. mieszkańców, położonym nieopodal wschodniej granicy Białymstoku aż do 2007 r. władze miasta nie zezwoliły na budowę żadnych nowoczesnych galerii handlowych, a jedynym wielkopowierzchniowym obiektem handlowym był otworzony w 2000 r. hipermarket Auchan.

Galeria Alfa znajduje się w bliskim sąsiedztwie rynku i ulicy Lipowej, zlokalizowano ją w zabytkowych budynkach dawnej fabryki. Szczególnie szeroka w Galerii Alfa jest oferta odzieżowa, usługowa oraz kulturalno-rozrywkowa. Znajdują się tu dwa kina, ścianka wspinaczkowa, klub sportowy, miejsce zabaw dla dzieci oraz przestrzeń biurowa. Przestrzeń i oferta zlokalizowanej nieco dalej od centrum miasta Galerii Biała jest zdecydowanie mniej nowoczesna i zróżnicowana.

Analizując rozwój infrastruktury przestrzeni konsumpcji w Białymstoku, nie można pominąć wpływu „zakupowych turystów” z Białorusi, którzy regularnie przybywają na zakupy w tym mieście. Białorusini przyjeżdżają zarówno prywatnymi samochodami, jak i jako uczestnicy zorganizowanych przez biura podróży wycie-

34 Ibidem.

35 Strona internetowa Galerii Korona, http://www.galeria-korona.pl/eventy/W-najbli\%C5\%BCszymczasie.html, dostęp 14.11.2013.

36 Strona internetowa hipermarketu Auchan, http://www.auchan.pl/auchan-bialystok-produkcyjna/ historia-sklepu, dostęp 16.11.2013. 
czek $^{37}$, przyjeżdżają mimo konieczności zapłacenia za wizę oraz zablokowania przez władze Białorusi ustawy o małym ruchu granicznym ${ }^{38}$.

Kolejną omawianą w opracowaniu galerią handlową jest Manufaktura w Łodzi. Badacze przestrzeni Łodzi podkreślają często, że w mieście do 2006 r. brakowało infrastruktury przestrzeni konsumpcji umożliwiającej organizację wydarzeń i imprez ogólnomiejskich ${ }^{39}$. Brak ten dostrzegli inwestorzy, którzy zrewitalizowali położoną nieopodal Starego Miasta dawną fabrykę włókienniczą i stworzyli w niej centrum kulturalno-rozrywkowo-handlowe o nazwie nawiązującej do przeszłości miasta Manufaktura.

Manufaktura ma w swojej ofercie sklepy, restauracje, kina i dyskoteki, a także muzea: Muzeum Fabryki, Muzeum Sztuki, Muzeum Historii Łodzi oraz trzyhektarowy rynek, który jest jej punktem centralnym i pełni funkcję otwartej przestrzeni publicznej ${ }^{40}$. Odbywają się na nim imprezy kulturalne, koncerty łódzkich muzyków, zabawy sylwestrowe, latem tworzona jest tu plaża, zimą lodowisko, tu gra Wielka Orkiestra Świątecznej Pomocy. W 2009 r. skończono również budowę zlokalizowanego w budynku starej przędzalni Hotelu Andel's. Centrum handlowe reklamuje się sloganem „Manufaktura napędza Łódź”41 , który zdaniem właściciela centrum handlowego oddaje istotę jego istnienia i funkcjonowania. Na stronie internetowej pojawiają się również określenia takie jak „bijące serce Łodzi”, „nowe centrum miasta”, „wizytówka miasta”, „najbardziej rozpoznawalny symbol miasta” ${ }^{2}$, a także twierdzenia przypominające o historycznej wartości budynków, w których mieści się Manufaktura, takie jak „unia przeszłości z przyszłością, połączenie historii z nowoczesnością" ${ }^{43}$. Badacze przestrzeni miejskiej wskazują na bardzo duże znaczenie Manufaktury w „ożywianiu” przestrzeni publicznej w Łodzi, uważają ją za ważny i charakterystyczny element tworzenia wizerunku miasta ${ }^{44}$.

${ }^{37}$ Stwierdzam to na podstawie własnych obserwacji, rozmów z białostoczanami, sprzedawcami w galeriach handlowych oraz analizy treści prasy lokalnej (np. A. Poczobut, Białystok $w$ białoruskich mediach: miasto tanich zakupów, gazeta.pl, 17.01.2013, http://bialystok.gazeta.pl/bialystok/1,35235,13254628,Bialystok_w_bialoruskich_mediach_miasto_tanich_zakupow.html, dostęp 15.11.2013; Szał zakupów. Białorusini kupili u nas towary za blisko $800 \mathrm{mln}$ złotych, 29.01.2013, http://www.wspolczesna.pl/apps/pbcs.dll/ article?AID=/20130129/REG00/130129589, dostęp 15.11.2013.

${ }_{38}$ Mały ruch graniczny $z$ Białorusia wstrzymany. Polska musi poczekać na Litwę, 15.01.2013, gazeta.pl, http://bialystok.gazeta.pl/bialystok/1,35241,13215773,Maly_ruch_graniczny_z_Bialorusia_wstrzymany_ Polska.html, dostęp 15.11.2013.

${ }^{39}$ M. Sobczyński, A. Wolaniuk, op.cit., s. 28.

${ }^{40}$ Strona internetowa Manufaktury, http://www.manufaktura.com/26/o_nas, dostęp 18.11.2013.

${ }^{41}$ Ibidem.

42 Ibidem.

${ }^{43}$ Strona internetowa Manufaktury, http://www.manufaktura.com/22/rewitalizacja, dostęp 20.11.2013.

${ }^{44}$ M. Sobczyński, A. Wolaniuk, op.cit. 
Wszystkie analizowane galerie handlowe znajdowały się w centrach miast, trzy z nich wybudowano bezpośrednio przy głównym deptaku handlowym, trzy powstały w zrewitalizowanej przestrzeni. Adaptacja zabytkowych fabryk wiąże się z wyższymi kosztami niż budowa budynku od fundamentów, wydłuża proces inwestycji, ale przyczynia się do pozytywnego postrzegania obiektu, darmowej promocji w prasie lokalnej i branżowej, daje możliwość stworzenia otoczki centrum kultury, mówienia o ratowaniu dziedzictwa historycznego i budowaniu tożsamości miasta. Daje również możliwość zlokalizowania centrum handlowego na atrakcyjnym centralnym terenie oraz perspektywę promocji inwestycji jako odpowiedzialnej społecznie, zlokalizowanej na niegdyś zaniedbanych terenach. W tabeli 1 pokazuję ofertę handlowo-usługową galerii handlowych, wskazuję, jak bardzo zróżnicowane i liczne usługi różnych rodzajów oferuje każda z nich. Największe analizowane galerie, biorąc pod uwagę liczbę sklepów z odzieżą (właśnie ta kategoria różnicuje je najwyraźniej), to: Manufaktura w Łodzi i Stary Browar w Poznaniu, nieco mniejsza jest Galeria Echo w Kielcach. Liczba sklepów pozostałych kategorii zmienia się proporcjonalnie do wielkości obiektu - wyjątkiem są tu kawiarnie i restauracje, które niezależnie od wielkości centrum handlowego zawsze pozostają na poziomie porównywalnym do drugiej galerii handlowej w danym mieście. W każdej z analizowanych galerii występowała szeroka oferta w dziedzinie usług i finansów, w większości można skorzystać z usług przynajmniej jednego optyka, biura podróży, jest apteka i kwiaciarnia. Każda $\mathrm{z}$ badanych galerii handlowych oferowała możliwości rozrywek, w najmniejszej z nich było to tylko kino, ale już w Manufakturze aż 13 lokali tego typu.

Tabela 1. Rodzaje punktów handlowo-usługowych w najważniejszych galeriach handlowych w pięciu badanych miastach w 2013 r.

\begin{tabular}{|l|c|c|c|c|c|c|}
\hline $\begin{array}{c}\text { Rodzaj punktu } \\
\text { handlowo-usługowego }\end{array}$ & $\begin{array}{c}\text { Liczba } \\
\text { punktów } \\
\text { w Starym } \\
\text { Browarze }\end{array}$ & $\begin{array}{c}\text { Liczba } \\
\text { punktów } \\
\text { w Galerii } \\
\text { Echo }\end{array}$ & $\begin{array}{c}\text { Liczba } \\
\text { punktów } \\
\text { w Galerii } \\
\text { Korona }\end{array}$ & $\begin{array}{c}\text { Liczba } \\
\text { punktów } \\
\text { w Galerii Alfa }\end{array}$ & $\begin{array}{c}\text { Liczba } \\
\text { punktów } \\
\text { w Galerii } \\
\text { Biała }\end{array}$ & $\begin{array}{c}\text { Liczba } \\
\text { punktów } \\
\text { w Manufak- } \\
\text { turze }\end{array}$ \\
\hline Odzież & 83 & 78 & 40 & 64 & 32 & 86 \\
\hline $\begin{array}{l}\text { Restauracje, cukiernie, } \\
\text { kawiarnie }\end{array}$ & 32 & 19 & 15 & 9 & 9 & 39 \\
\hline $\begin{array}{l}\text { Sklepy z obuwiem } \\
\text { i galanterią skórzaną }\end{array}$ & 27 & 22 & 10 & 17 & 15 & 22 \\
\hline Biżuteria i dodatki & 13 & 22 & 7 & 9 & 6 & 24 \\
\hline Usługi i finanse & 13 & 13 & 4 & 10 & 6 & 13 \\
\hline $\begin{array}{l}\text { Aranżacje i wyposażenie } \\
\text { wnętrz }\end{array}$ & 11 & 13 & 1 & 4 & 1 & 15 \\
\hline Artykuły spożywcze & 8 & 6 & 3 & 3 & 1 & 15 \\
\hline Książki, prasa, upominki & 8 & 5 & 5 & 2 & 2 & 7 \\
\hline
\end{tabular}




\begin{tabular}{|l|c|c|c|c|c|c|}
\hline $\begin{array}{c}\text { Rodzaj punktu } \\
\text { handlowo-usługowego }\end{array}$ & $\begin{array}{c}\text { Liczba } \\
\text { punktów } \\
\text { w Starym } \\
\text { Browarze }\end{array}$ & $\begin{array}{c}\text { Liczba } \\
\text { punktów } \\
\text { w Galerii } \\
\text { Echo }\end{array}$ & $\begin{array}{c}\text { Liczba } \\
\text { punktów } \\
\text { w Galerii } \\
\text { Korona }\end{array}$ & $\begin{array}{c}\text { Liczba } \\
\text { punktów } \\
\text { w Galerii Alfa }\end{array}$ & $\begin{array}{c}\text { Liczba } \\
\text { punktów } \\
\text { w Galerii } \\
\text { Biała }\end{array}$ & $\begin{array}{c}\text { Liczba } \\
\text { punktów } \\
\text { w Manufak- } \\
\text { turze }\end{array}$ \\
\hline Kosmetyki & 7 & 12 & 7 & 7 & 4 & 11 \\
\hline Sport & 7 & 13 & 5 & 3 & 4 & 11 \\
\hline Telefonia komórkowa & 7 & 5 & 3 & 2 & 4 & 4 \\
\hline Artykuły dziecięce & 6 & 7 & 2 & 3 & 4 & 12 \\
\hline Kultura i rozrywka & 5 & 5 & 6 & 5 & 1 & 13 \\
\hline Multimedia, RTV, AGD & 9 & 12 & 2 & 4 & 2 & 9 \\
\hline Alkohole i cygara & 3 & 1 & 0 & 0 & 0 & 1 \\
\hline Apteka & 2 & 1 & 1 & 1 & 1 & 2 \\
\hline Optyk & 2 & 4 & 2 & 1 & 2 & 4 \\
\hline Kwiaciarnia & 2 & 1 & 1 & 1 & 1 & 0 \\
\hline Biura podróży & 1 & 3 & 2 & 1 & 2 & 5 \\
\hline Instrumenty muzyczne & 1 & 0 & 0 & 0 & 0 & 0 \\
\hline
\end{tabular}

Źródło: Opracowanie własne na podstawie stron internetowych: Galerii Handlowej Stary Browar, http://starybrowar5050.com; Galerii Echo, http://www.galeriaecho.pl/; Galerii Korona, http://www.galeria-korona.pl/; Galerii Alfa, http://www.alfacentrum.com.pl/bialystok/; Galerii Białej, http://www.atrium-biala.pl/; Centrum handlowego Manufaktura, http://www.manufaktura.com/.

\section{Zakończenie}

Infrastruktura miejskiej przestrzeni konsumpcji pełni wiele bardzo ważnych funkcji - zarówno dla miasta, jak i dla jego mieszkańców. Są to funkcje ekonomiczne, społeczne oraz architektoniczno-urbanistyczne. Jednak znaczenie poszczególnych typów infrastruktury przestrzeni konsumpcji w każdym z badanych miast różni się, decydują o nim zarówno historyczne uwarunkowania, jak i polityka i działania władz miejskich, działalność inwestorów i deweloperów oraz coraz bardziej aktywna postawa mieszkańców miast domagających się możliwości współrządzenia.

Historia wykształciła w Polsce dwa typy miast: $\mathrm{z}$ dominującym znaczeniem rynku lub dominującym znaczeniem ulicy handlowej. Współczesne działania władz miasta wpływają na zmianę znaczenia poszczególnych typów infrastruktury przestrzeni konsumpcji. Dla społecznego i ekonomicznego znaczenia tych przestrzeni szczególnie istotne są przeprowadzane rewitalizacje przestrzeni, wyłączanie ich z ruchu samochodowego, a także organizowanie wydarzeń, które zachęcają mieszkańców do spędzania czasu wolnego na rynkach i głównych ulicach handlowych. Na znaczenie rynków i ulic handlowych w badanych miastach duży wpływ miało otwieranie kolejnych, zlokalizowanych w centrum miasta galerii handlowych. Obecność 
nowoczesnych obiektów handlowych oferujących coraz więcej usług przyczynia się do osłabienia handlowego i społecznego znaczenia pozostałych dwóch typów infrastruktury miejskiej przestrzeni konsumpcji. O atrakcyjność oferty galerii handlowej dba sztab specjalistów, nadeszły czasy, gdy również o atrakcyjność przestrzeni rynku i ulicy handlowej należy zadbać, gdyż najwyraźniej tradycja i tożsamość zapisana $\mathrm{w}$ ich strukturze nie są wystarczającymi przewagami, by konkurować $\mathrm{z}$ nowoczesnymi obiektami handlu i rozrywki.

\section{Infrastructure of consumption space in contemporary municipalities in Poland}

The importance of particular types of infrastructure of consumption space in each of the analyzed municipalities is different, due to the historical conditions and policies and actions of municipal authorities, investors, and increasingly active residents. Until the advent of modern shopping malls into town centers, markets and shopping streets were very important for consumption in towns. The presence of modern shopping malls contributes to the weakening of the commercial and social significance of the other two types of urban infrastructure of consumption space. In order to prevent those negative trends local authorities invest in revitalization, changing traffic patterns and public festivities.

Keywords: urban infrastructure of consumption space, shopping street, market, shopping mall, city, Kielce, Białystok, Poznań, Łódź

\section{L'infrastructure des lieux de consommation dans les villes modernes en Pologne}

Limportance de types particuliers de l'infrastructure des lieux de consommation dans chacune des villes analysées est différente en raison des conditions historiques ainsi que des politiques et des actions des autorités locales, investisseurs et résidents très actifs. Jusquà l'avènement des centres commerciaux modernes dans les centres-villes, ce sont les marchés et les rues commerçantes qui ont joué un rôle important dans la consommation dans les villes. Les centres commerciaux modernes contribuent à l'affaiblissement de l'importance commerciale et sociale de deux autres types d'infrastructure urbaine des lieux de consommation. Pour 
éviter ces tendances négatives, les autorités locales investissent dans la revitalisation, l'évolution des modes de circulation et les festivités publiques.

Mots-clés: l'infrastructure urbaine des lieux de consommation, la rue commerçante, le marché, le centre commercial, la ville, Kielce, Bialystok, Poznan, Lodz

\section{Инфраструктура пространства потребления в современных городах Польши}

Значение отдельных видов инфраструктуры пространства потребления в каждом из анализируемых городов отличается в силу исторических условий, политики и действий муниципальных властей, инвесторов и все больше и больше активных жителей. До появления современных торговых центров в городских центрах, рынки и торговые улицы были очень важны. Наличие современных торговых центров способствует ослаблению коммерческой и социальной значимости этих двух других типов городской инфраструктуры пространства потребления. В целях предотвращения этих негативных тенденций местные власти должны проводить ревитализацию, инвестировать в изменения схемы дорожного движения и в общественные праздники.

Ключевые слова: городская инфраструктура пространства потребления, торговая улица, рынок, торговый центр, город, Кельце, Белосток, Познань, Лодзь 